diseases and, where indicated, to increase their efforts to combat, at the national level, the recrudescence of these infections".

\section{Psychiatry in General Practice}

A price has to be paid for evory advance in medicine. With montal disease, for example, an increasing burden is laid on the family doctor by the policy of the "open door'. The wisdom or charity of this new concept of retaining the mentally disturbed patient in the community is generally accepted, aithough the furnily doctor may wonder whethor the enthusiastic progonitors of the concept have ever realized what it moans to him. $\mathrm{He}$ is willing to cope with the situation to the best of his ability, and the airn of a symposium in The Practitioner (194, No. 1163; I965) is to holp him in his onorous task. In the available space only a few aspects of the subject are considered. Those included have boon solected oither bocause they represent conditions commonly oncountered, such as depressive illness which, as Dr. J. Pollitt points out, is the commonest psychiatric condition in general practice, or doal with new developments in this field such as therapeutic communities. The symposium concludes with an article on "The Neurotic in Genoral Practice", which epitomizes one of the most worrying problems facing the family doctor at the present moment. Dr. N. Kessel notes that "Until the theoretical understanding of how to treat neurosis is achievod, until thore is considerably more money to spend within the N.H.S. INational Health Service], the problem of how to manage the mass of neurotic patients known to their doctors cannot be satisfactorily solved". This gloomy outlook is relieved by the evidence that "there is a high proportion of spon. taneous remissions". In other words. "most neurotic patients get better".

\section{The International Hydrological Decade}

Is November 1961, on the authority of the U.S. Depart ment of State, a resolution was tendered to the Executive Board of Unesco ". . . calling attention to the importance of scientific hydrology and recommending that a meeting of experts should be convened, to examine the proposition to institute an international programme for hydrology, extending over a ten-year period". The General Conference of Unesco, in November 1964, approved the plans prepared by meetings of these experts for an International Hydrological Decade, to start in January 1965. The events leading up to this decision have been recorded by $R$. L. Nace in a paper entitled "The International Hydrological Decade" (Trans. Amer. Geophys. Union, 45, $413 ; 1964)$; a later and succinct account of the whole project is contained in an article similarly titled by E. S. Hills (Austral. ,J. Sci., 27, 10; April 1965). This sots forth the main objectives of the scheme, which may be summarized as follows: (a) appraisal of the state of knowledge of world hydrology and identification of the principal gaps in that knowledge; (b) standardization of instruments, observations, techniques and termin. ologies used for compilation and reporting of data; (c) establishment of basic networks and improvements of oxisting networks to provide fundamental data on hydrological systems covering small watersheds to the world as a whole; (d) research on hydrological systoms in selected environments, called 'representative basins'; (e) research on specific hydrological problems tho urgency and special natureof which demand action at international level; ( $f$ ) theoretical and practical training in hydrology and rolated subjects; $(g)$ systematic exchange of information. E. S. Hills is chairman of the Australia-Unesco Committee for the International Hydrological Decade and in his article he gives a brief account of Australian participation in this laudable and vital scheme. This is followod in tho same issue of the Journal by an important paper entitled "Water-Essential Factor of Economic Develop- ment", by R. L. Nace (U.S. (xeological Survey), reproduced from Impact $(14 ; 1964)$; much of the background, both theoretical and technical, of the International Hydrological Decade is disclosed in this essay. The German version of this project is described in an article "Die Internationale Hydrologische Dekade (IHD)" by U. de Haar, Bad Godesborg (Umschau in Wissenschaft und Technik, Frankfurt/M, 14; July 1965); this includes a novel diagram in colour depicting the incidence and passage of rainfall in its circulation on and below the surface of the Earth, what is lost, what is used, and how the inevitable water-cycle is completed.

\section{History under the Sea}

THE Smithsonian Institution has provided a very usoful compondium of the rapidly growing work of underwater oxploration in a book, History under the Sea, by Mendel Peterson (Pp. xiii $+108+56$ plates, publication 4538. Washington, D.C.: Smithsonian Institution, 1965). The subjoct is treatod from all aspocts and oven discusses modern methods of spotting underwater wrecks by magnetometers and induction detectors. A useful section is dovoted to the preservation of materials recovered from the water, both as regards first-aid work in the fiold and subsoquont treatment in the laboratory. A selected bibliography and illustrations of typical finds complete this ominently worth-while publication.

\section{Photography and the Graphic Arts}

There are many publications catoring for the interests of photographers, both amateur and professional, but one entitled Visual is perhaps not so widely known as it deserves to be. Visual is the house organ of Ilford Ltd. (Forguson House, 15-17 Marylebone Road, London, N.W.1), and appears three times annually. Two recent copies (2, No. $3 ; 1964$, and 3 , No. $1 ; 1965$ ) are notable both for contents and certainly for the excellence of the black-and-white and colour illustrations generously distributed throughout the texts, as one would naturally expect from this particular firm. Among the titles in the former issue is "Assignment Tokyo", depicting briefly, in colour, contemporary life in this modern Japanese city; an account of the activities of the Institute of Incorporated Photographers; papers on "Photographic Paper Base", "Medical Photography", and "The Production of Photolitho Printing Surfaces for Offeet Printing". In the more recont issue there are articles on "The Polytechnic Contribution to the Development of Photography"; "Printing and Publishing-15 Years Hence?"; "Photographic Processing Chemicals". The journal also includes an article entitled "Profile: Douglas F. Lawson", dealing with this internationally recognized authority on photomicrography; the colour illustrations to this are quite outstanding, ranging in subject from aspirin crystals, marine-floor foraminifera, natural onyx stone, section of a cat's tongue showing the surface hairs, and the eggs of a moth, to a section of fusod phloridzin, and a reproduction of a slide of Amphioxus, part colour, which demonstrates the value of annotated drawings to accompany photomicrographs. Incidentally, as mentioned in this article, D. F. Lawson is the author of the well-known Technique of Photomicrography; his work ". . . has been reproduced in hundreds of publications in many parts of the world, and used in educational television programmes". $V$ isual is yet another oxample of a high-cless house magazine wheroin advertisement is relegated to a modest background (a brief section entitled "Ilfordia") and the major appeal to the reador made by the quality of its contents, by its inviting format, and especially by its beautiful illustrations.

\section{Creep and Shrinkage of Concrete}

Articles, papers and books dealing with the subject of creep and shrinkage of concrete, held by the library of 